\title{
Health impact of unicellular algae of the Ostreopsis genus blooms in the Mediterranean Sea: experience of the French Mediterranean coast surveillance network from 2006 to 2009
}

Lucia Tichadou $^{1}$, Mathieu Glaizal ${ }^{1}$, Alexis Armengaud ${ }^{2}$, Hubert Grossel ${ }^{3}$, Rodolphe Lemée ${ }^{4,5}$, Roger Kantin $^{3}$, Jean-Luc Lasalle ${ }^{2}$, Genevève Drouet ${ }^{1}$, Loïc Rambaud ${ }^{6}$, Philippe Malfait ${ }^{2}$, and Luc de Haro ${ }^{1,{ }^{*}}$

\footnotetext{
${ }^{1}$ Centre Antipoison, hôpital Salvator, Marseille, France

${ }^{2}$ Cellule interrégionale d'épidémiologie sud, Drass PACA, Marseille, France

${ }^{3}$ Institut français de recherche pour l'exploitation de la mer (IFREMER), La Seyne sur Mer, France

${ }^{4}$ Université Pierre et Marie Curie - Paris 6, Laboratoire d'Océanographie, Villefranche-sur-Mer, France

${ }^{5}$ CNRS, Marine Microbial Ecology Group, Laboratoire d'Océanographie, Villefranche-sur-Mer, France

${ }^{6}$ Institut de Veille Sanitaire, Département Santé Environnement, Saint Maurice, France

\author{
*: Corresponding author : Luc de Haro, Tel.: +33 4917525 25; fax: +33 4917441 68, email address : \\ luc.deharo@ap-hm.fr
}

\begin{abstract}
:
Objective. Ostreopsis ovata and Ostreopsis siamensis are tropical unicellular algae that have been found recently in the Mediterranean. Both of these dinoflagellates produce palytoxin (PTX)-like toxins that are powerful vasoconstrictors in mammals. Since 2003, Ostreopsis blooms in Italy and Spain have been accompanied by reports of respiratory problems and skin/mucosa irritation in persons in contact with toxic microalgal cells (epiphytes, plankton, or sea spray) or associated toxins. Methods. In France, a surveillance network has been set up to monitor water conditions and to protect swimmers from contamination due to Ostreopsis. Results. Between 2006 and 2009, a total of nine blooms were observed on the French Mediterranean coast including five that led to manifestations in divers, swimmers, and shoreline inhabitants. A total of 47 patients presented symptoms of involving benign or mild skin, mucosal, and/or respiratory irritation that regressed spontaneously without treatment within 12-72 h (4-12 h with nonsteroidal anti-inflammatory drugs). During the study period, five beaches were temporarily closed. Discussion. In the Mediterranean, Ostreopsis blooms induce skin and respiratory disorders when human beings are exposed to saltwater with a high concentration of algal cells. However, palytoxin dosages carried out on the food chain (urchins, mussels) indicate that this risk of toxins accumulation in seafood must be taken into account and that the surveillance network should be upgraded accordingly.
\end{abstract}

Keywords: Dinoflagellate, Algal bloom, Ostreopsis, Mediterranean Sea, Palytoxin 


\section{Introduction}

Two tropical benthic dinoflagellate species of the Ostreopsis genus have colonized waters in temperate zones. One of these expanding species is $O$. siamensis that is already well established in Japan, Australia, and New Zealand [1] and in the Mediterranean [2]. The second species is the smaller $O$. ovata. Its regular presence did not cause any particular problems until 2000 when the first blooms occurred [3] and this species has now become a major health problem in the Mediterranean [4, 5].

In the Mediterranean, Ostreopsis species develop preferentially on plants living at shallow depths such as macroalgae or phanerogames. When conditions are favorable, in summer months, Ostreopsis can proliferate and create massive floating clusters (figure 2). These clusters are suspended near the water surface and toxic cells and/or associated toxins released due to cell lysis can be aerosolized in sea spray. The first isolated cases of respiratory symptoms in persons exposed to sea spray were reported in August 2003 and September 2004 in Bari, Italy [6] and in August 2004 near Barcelona, Spain [7]. However, it was in 2005 in Genoa, Italy that the phenomenon took on major proportions when respiratory manifestations were observed in around 200 persons who inhaled contaminated sea spray $[4,8]$. Since that first observation, similar events have been documented not only in Italy [4, 9] and Spain [10] but also in France [7], Croatia, Tunisia and Greece [1]. In the summer of 2009, several local news outlets reported blooms involving numerous symptomatic patients in Algeria.

$O$. ovata and $O$. siamensis in the Mediterranean produce toxins similar to palytoxin (PTX) called ostreocins (PTX-like) [11, 12]. Like PTX, PTX-like toxins are powerful vasoconstrictors that are highly toxic for mammals including humans. In tropical environments, PTX and PTXlike toxins are produced by several marine organisms including Ostreopsis and can accumulate along the food chain. Contaminated crustaceans and fish can become highly toxic for human consumption $[13,14]$. Until now, human poisoning due to consumption of shellfish or fish containing palytoxin like substances has not been reported in the Mediterranean. The main problem has been symptoms caused by direct exposure to these unicellular algae during sudden proliferation. In response to these risks, a surveillance network has been setup. The purpose of this report is to describe the French Mediterranean Ostreopsis Surveillance Network and present its results between its founding in 2006 and 2009, in order to evaluate the health impact of the emerging problem of Ostreopsis blooming.

\section{Method}

Following the 2005 reports describing the mass effects of Ostreopsis blooms on public health in Italy, a surveillance network was set up in France. The goal is to prevent human health problems by detecting and responding to Ostreopsis bloom events in recreational waters along the French Mediterranean coast. The French Mediterranean Ostreopsis Surveillance Network operates on an active basis during the blooming period from June 15 to September 15 providing:

- a health vigilance system to detect suspected cases due to exposure to Ostreopsis through direct contact with contaminated sea water or inhalation/contact with contaminated sea spray;

- environmental monitoring of Ostreopsis by visual observation of recreational waters and by testing water samples on a routine basis and in case of detection or alerts;

- Coordination with other environmental and health surveillance agencies and issuing appropriate recommendations regarding control and management.

The network unites a wide range of actors from the public health, scientific, and medical sectors. Public health officials are from all levels of government including not only the department, region and nation but also town halls. Scientific expertise is provided by the 
"InVS" ("Institut de veille sanitaire" or in English "French Institute for Public Health Surveillance") and its local branches called "Cire" (Interregional Epidemiological Units) in charge of evaluating health risks and by specialized laboratories including the French Research Institute for Exploitation of the Sea (IFREMER), the Villefranche Oceanography Laboratory (CNRS UMR 7093), and several certified laboratories. Medical advice is provided by the Poison Control Center in Marseille that is a clinical toxicology unit serving the entire French Mediterranean coast from Spain to Italy including Corsica on a 24/7 basis. The Marseille Poison Control Center also receives requests for assistance from inhabitants and from medical facilities in Monaco that do not have a poison control center.

The period of active surveillance, from June 15 to September 15, corresponds to the time that is most favorable for Ostreopsis blooming $[1,5]$ and to the peak season for recreational water use. During the active surveillance period, a weekly update is sent to all participants in the surveillance network. When there is an alert, permanent contact is maintained between the different network members. Alerts can be raised by two processes. The first one is through the Poison Control Center after detection of at least two patients with clinical symptoms compatible with exposure to contaminated seawater in the same location. The clinical observations were included in our results when symptoms were compatible with exposure to Ostreopsis and laboratory findings confirm the presence of unicellular algae. The second is based on routine analysis showing levels exceeding the threshold of 30,000 Ostreopsis cells (defined on an empirical basis in 2009, based on sea water analysis experience as published in reference 7 ) in zones of known contamination by IFREMER, the Villefranche Oceanography Laboratory, or certified laboratory following the guidelines of the Social and Health Affairs Department (French acronym, DDASS). For both alert processes, the General Health Administration has issued specific guidelines and, when there is an alert, a crisis team is formed by all network members to define adequate measures to protect the population. Measures can include prohibiting public access to contaminated beaches and/or consumption of shellfish and fish. Serial analysis of Ostreopsis concentrations is then begun and protective measures are maintained until results confirm that the bloom is over.

\section{Results}

Data collected by French Mediterranean Coast Ostreopsis Surveillance Network from its inception through 2009 are presented in table 1. A total of 47 suspected cases of Ostreopsis poisoning were followed up by the Marseille Poison Control Center in conjunction with 5 documented blooms identified by environmental surveillance. The environmental surveillance allowed discovering 4 more blooms which were not linked with human exposure. Public protection measures taken in response to the blooms prevented further contamination (swimming not recommended with information of beach-goers by local authorities or forbidden beach with police and coast guard intervention). $O$. ovata blooms were observed between Marseille and the Italian border, including Monaco and 3 French departments (table 1). Surveillance data showed recurrent colonization in waters with favorable conditions, i.e., areas protected by jetties or rocks where turnover is limited and sunshine raises temperatures (However blooms have also been observed in unprotected rocky zones, e.g., on the Reserve Beach in Nice in 2008). Recurrent blooms were observed in 2006, 2008, and 2009 in Morgiret creek on the Frioul Island in Marseille and in 2008 and 2009 in the "Marinière Beach" at the tip of the cove in Villefranche-sur-Mer near Nice. The latter beach was closed both years.

Analysis of the data collected by environmental surveillance indicated that August was the peak bloom time accounting for $75 \%$ of the blooms observed. However blooms were also observed after several days of sunshine in July and even in June or September (chronological distribution of the blooms in table 1).

Clinical findings observed after direct exposure to $O$. ovata were variable. Skin irritation was the most common manifestation. It might be the only sign if Ostreopsis is present at low concentration in the water and remains mainly attached to macrophytes (initial bloom phase). 
This was the case in August 2009 for 10 teenagers who waded for a long period at a beach where the water was rich in macrophytes on which Ostreopsis had proliferated with a low proportion of plankton cells. Clinical examination in these 10 patients showed erythema on the lower extremities that regressed rapidly after exposure ended. With higher quantities of microalgae in the water, clinical findings in exposed patients were more extensive with puritis on exposed skin, conjunctivitis with tearing, rhinorrhea, and oral irritation. In the most severe cases, e.g., in divers or persons subjected to prolonged respiratory exposure, general flu-like symptoms were observed including headache, joint pain, vertigo, fever, fatigue, and, in some cases, digestive manifestations and diarrhea.

In our series, outcome was favorable in all patients within 12 to 72 hours without treatment and 4 to 12 hours after treatment using non-steroidal anti-inflammatory drugs. The mainstay of treatment was decontaminating the exposed surfaces by showering the body and rinsing mucosa with saline. If possible, non-corticosteroid inflammatory agents may be administered to improve patient comfort. Of the 47 patients in this series, only one 8-year-old girl required admission to the hospital that consulted the Marseille Poison Control Center within 20 minutes after contamination at the Larvotto beach in Monaco in July 2008. The girl presented dyspnea caused by extensive rhinorrhea and bronchorrhea. Despite extensive irritation involving the mouth and the upper airways tract, the patient responded favorably to antiinflammatory agents and was considered as cured within 8 hours. Medical management was not necessary for the remaining patients.

\section{Discussion}

There is a paucity of literature addressing skin/mucosa exposure by PTX and PTXlike toxins. A few recent reports described clinical presentation including systemic symptoms after skin or respiratory contact with soft coral in the Zooanthides family, i.e., Zoanthus and Palythoa genera (toxin named after the latter), that concentrate large quantities of PTX. All cases reported involved aquarium keepers who were exposed to these sessile invertebrates [15-17].

Experience in Italy, Spain, and France has provided better insight into cutaneous, mucosal, and respiratory exposure associated with Ostreopsis blooms. Symptoms are mainly due to direct irritation of tissues exposed to seawater with high microalgae levels. Flu-like manifestations including headache, mild gastrointestinal problems, and fever have been reported to an as-yet undetermined degree. Dyspnea due to hypersecretion and/or bronchospasm has been observed in the most severe cases. The only previously reported model in which skin/mucosa irritation and respiratory symptoms have been observed after inhalation of seawater spray during unicellular algal blooms involved the dinoflagelate Karenia brevis in the Gulf of Mexico (Florida and Texas). The latter dinoflagelate produces large quantities of toxins called Brevetoxins $[18,19]$. These toxins that are unrelated to PTX have been implicated in respiratory symptoms including recurrent bronchospasms in shoreline dwellers and workers contaminated during blooms.

The results presented here indicate that the exposed patient management is generally straightforward. The greatest concern raised by the possibility of contamination by inhalation of seawater spray is a mass poisoning incident involving several hundred persons within a few hours as was observed in Liguria near Genoa in 2005. A sudden influx of patients can quickly overload emergency care facilities and thus must be avoided. For obvious reasons, the population at greatest risk for poisoning are swimmers who come in direct contact with Ostreopsis cells either attached to macroalgae (epiphyte cells) or released into the water (planktonic cells). For snorkeling or scuba diving, the use of mouth breathing devices (snorkels or regulators) may promote formation of micro-droplets of saltwater contaminated with unicellular algae that can thus be inhaled deeply into the airways. This mechanism could explain why some divers present general as well as local manifestations. Skin and respiratory symptoms have also been observed in beach walkers exposed to sea spray. Persons working for the surveillance network and in particular scientific personnel in charge 
of collecting samples are at high risk for exposure to Ostreopsis. This risk was confirmed by a case observed in 2009 involving a patient contaminated while collecting samples at the peak of a bloom in Villefranche-sur-Mer (table 1).

Although all manifestations observed in this series were benign, it should be emphasized that the best treatment is prevention. As indicated by the data in table 1, public protection measures such as prohibiting access or restricting swimming in contaminated areas can prevent clinical cases if weekly environmental testing detects blooming. Indeed surveillance network data showed no cases during the 4 blooms associated with Ostreopsis levels exceeding the alert threshold of 30000 cells per liter of seawater and mild weather conditions with no sea spray (table 1).

Another concern is contamination of the food chain by PTX-like toxins produced by Ostreopsis. Initial ecological data appears to show that Mediterranean marine organisms are susceptible to Ostreopsis blooms, with high mortality and morbidity having been observed in numerous species such as urchins and starfish [20, 21]. Previous data from tropical and subtropical areas (e.g. southern Japan) show that consumption of shellfish contaminated with PTX and PTX-like toxins is dangerous for humans [13]. Several case reports have described persons who died rapidly after eating crustaceans and fish containing these toxins. The clinical syndrome is called palytoxicosis when it involves consumption of crustaceans and parrotfish and clupeotoxism when it involves consumption of small pelagic fish such as sardines and mackerels $[14,22]$. The severity of poisoning is linked to the strong vasoconstricting properties of PTX and PTX-like toxins that can lead to various lifethreatening complications within a few hours including rhabomyolysis, myocarditis, and renal failure.

Up until now no data has been found to suggest that PTX-like toxins produced by Ostreopsis accumulate in the tissues of fish and crustaceans in the Mediterranean. However recent findings showed that PTX-like toxins accumulate in mussels attached near zones where Ostreopsis blooms have been observed as well as in urchins living in these sites. Studies carried out in Greece found high concentrations of PTX-like toxins in apparently healthy living mussels [23]. These observations were confirmed in 2009 (communication from Ifremer) with regard to mussels as well as to urchins with levels exceeding established thresholds now under evaluation at the international level. Thus the question may be raised about the risk for development of a new form of mytilism (intoxication due to ingestion of water filtering shellfish contaminated by dinoflagellate toxins) [24] in the Mediterranean due to contamination of shellfish by PTX-like toxins produced by Ostreopsis.

\section{Limitations}

This report describes the experience of the French surveillance network. However, it must be noted that the data presented here is subject to several limitations. One limitation involves the non-specific nature of clinical manifestations that probably resulted in underdiagnosis and, thus, under-reporting to the Poison Control Center. Another confounding factor is the impossibility of permanent monitoring of Ostreopsis in all recreational waters on the French Mediterranean coast. This study includes only clinical and medical data compiled by the Marseille Poison Control Center from France and Monaco (for sea water analysis and administrative decision concerning beach access, Monaco has its own surveillance network). Moreover, only cases in which Ostreopsis was considered as a plausible cause were included based on identification of compatible clinical features in at least 2 persons in a location where the presence of an Ostreopsis bloom was demonstrated based on laboratory findings. In this regard, it must be stressed that analysis of seawater and/or macrophytes could only be done the day after symptoms are reported and that several hours may elapse between the occurrence of symptoms on the one hand and reporting to the poison control center on the other. However we are aware that negative analytic results the day after 
reported symptoms are not sufficient to rule out exposure to Ostreopsis as the cause since blooms can be short and last only a few hours.

\section{Acknowledgments}

Monitoring of Ostreopsis concentration in Fréjus, Nice and Villefranche was carried out within the framework of the "MediOs 2" project funded by the "Ministère de l'Ecologie", "le Conseil Général 06" and the "Agence de l'eau RM\&C". Monitoring in Monaco was funded by "Direction Environnement de la Principauté". Monitoring on Frioul Island in Marseille (Morgiret creek) was carried out by IFREMER within the framework of a joint project with the "Direction générale de l'Alimentation (Ministère Français de l'Agriculture)" with technical support from the "Conservatoire Etudes Ecosystèmes Provence (CEEP)" of the Frioul Island Marine Park.

\section{References}

1. Shears NT, Ross PM. Blooms of benthic dinoflagellates of the genus Ostreopsis; an increasing and ecologically important phenomenon on temperate reefs in New Zealand and worldwide. Harmful Algae 2009; 8: 916-925.

2. Penna A, Vila M, Fraga S. Characterization of Ostreopsis and Coolia (dinophycea) isolates in the western Mediterranean Sea based on morphology toxicity and internal transcribed spacer 5.8S rDNA sequences. J Phycol 2005; 41: 212-225.

3. Tognetto L, Bellato S, Moro I, Andreoli C. Occurence of Ostreopsis ovata (Dynophyceae) in the Tyrrhenian Sea during summer 1994. Botanica Marina 1995;38: 291-295.

4. Ciminiello P, Dell'Aversano C, Fattorusso E, Forino M, Tartaglione L, Grillo C, Melchiorre N. Putative palytoxin and its new analogue, ovatoxin-a, in Ostreopsis ovata collected along the Ligurian coasts during the 2006 toxic outbreak. J Am Soc Mass Spectrom 2008; 19(1): 111-120.

5. Mangialajo L, Bertolotto R, Cattaneo-Vietti R, Chiantore M, Grillo C, Lemée R, Melchiorre $\mathrm{N}$, Moretto $\mathrm{P}$, Povero $\mathrm{P}$, Ruggieri, N. The toxic benthic dinoflagellate Ostreopsis ovata: quantification of proliferation along the coastline of Genoa, Italy. Mar Poll Bull 2008; 56: 1209-1214.

6. Gallitelli M, Ungaro N, Addante LM, Procacci V, Silveri NG, Sabba C. Respiratory illness as a reaction to tropical algal blooms occurring in a temperate climate. JAMA 2005; 293(21): 2599-25600.

7. Kermarec F, Dor F, Armengaud A, Charlet F, Kantin R, Sauzade D, Giannetti S, de Haro L. Les risques sanitaires liés à la présence d'Ostreopsis ovata dans les eaux de baignade ou d'activités nautiques. ERS 2008; 7 (5): 357-363.

8. Brescianini C, Grillo C, Melchiorre N, Bertolotto R, Ferrari A, Vivaldi B, Icardi G, Gramaccioni L, Funari E, Scardala S. Ostreopsis ovata algal blooms affecting human health in Genova, Italy, 2005 and 2006. Euro Surveill 2006; 11(9): E060907.

9. Durando P, Ansaldi F, Oreste P, Moscatelli P, Marensi L, Grillo C, Gasparini R, Icardi G, Collaborative Group for the Ligurian Syndromic Algal Surveillance. Ostreopsis ovata and 
human health: epidemiological and clinical features of respiratory syndrome outbreaks from a two-year syndromic surveillance, 2005-06, in north-west Italy. Euro Surveill 2007; 12(6): E070607.

10. Barroso Garcia P, Rueda de la Puerta P, Parron Carreno T, Marin Martinez P, Enriquez JG. Brote con sintomas respiratorios en la provincia de Almeria por una posible exposicion a microalgas toxicas. Gac Sanit 2008; 22(6): 578-584.

11. Cagide E, Louzao C, Espina B, Vieytes MR, Jaen D, Maman L, Yasumoto T, Botana LM. Production of functionally active palytoxin-like compounds by Mediterranean Ostreopsis cf. siamensis. Cell Physiol Biochem 2009; 23: 431-440.

12. Guerrini F, Pezzolesi L, Feller A, Riccardi M, Ciminiello P, Dell'Aversano L, Dello Lacovo E, Fattorusso E, Forino M, Pistocchi R. Comparative growth and toxin profile of cultured Ostreopsis ovata from the Tyrrhenian and Adriatic Seas. Toxicon 2010; 55(2-3): 211-220.

13. Deeds JR, Schwartz MD. Human risk associated with palytoxin exposure. Toxicon 2010; 56(2): 150-162.

14. Taniyama S, Arakawa O, Terada M, Nishio S, Takatani T, Mahmud Y, Noguchi T. Ostreopsis sp., a possible origin of palytoxin (PTX) in parrotfish Scarus ovifrons. Toxicon 2003; 42(1): 29-33.

15. Hoffmann K, Hermanns-Clausen M, Buhl C, Büchler MW, Schemmer P, Mebs D, Kauferstein S. A case of palytoxin poisoning due to contact corals through a skin injury. Toxicon 2008; 51: 1535-1537.

16. Majlesi N, Su MK, Chan GM, Lee DC, Grelle HA. A case of inhalation exposure to palytoxin. Clin Tox (Phila) 2008; 46(7): 637.

17. Nordt SP, Wu J, Zahller S, Clark RF, Cantrell FL. Palytoxin poisoning after dermal contact with zoanthid coral. J Emerg Med 2010; Epub ahead of print.

18. Cheng YS, Zhou Y, Pierce RH, Henry M, Baden DG. Characterization of Florida red tide aerosol and the temporal profile of aerosol concentration. Toxicon 2010; 55(5): 922-929.

19. Fleming LE, Bean JA, Kirkpatrick B, Cheng YS, Pierce R, Naar J, Nierenberg K, Backer LC, Wanner A, Reich A, Zhou Y, Watkins S, Henry M, Zaias J, Abraham WM, Benson J, Cassedy A, Hollenbeck J, Kirkpatrick G, Clarke T, Baden DG. Exposure and effect assessment of aerosolized red tide toxins (brevetoxins) and asthma. Environ Health Perspect 2009; 117(7): 1095-1100.

20. Di Turi L, Lo Capito S, Marzano MC, Pastorelli AC, Pompei M, Rositani L, Ungaro N. Sulla presenza di Ostreopsidiaceae (Dinophyceae) lungo il litorale Barese. Biol Mar Medit 2003; 10(2): 675-678.

21. Sansoni G, Borghini B, Camici G, Cassoti M, Righini P, Rustighi C. Fioriture algali di Ostreopsis ovata (Gonyaulacales: Dinophyceae): un problema emergente. Biologia ambientale 2003; 17(1): 17-23.

22. Onuma $Y$, Satake M, Ukena T, Roux J, Chanteau S, Rasolofonirina N, Ratsimaloto M, Naoki $\mathrm{H}$, Yasumoto $\mathrm{T}$. Identification of putative palytoxin as the cause of clupeotoxism. Toxicon 1999; 37(1): 55-65. 
23. Aligizaki K, Katikou P, Nikolaidis G, Panou A. First episode of shellfish contamination by palytoxin-like compounds from Ostreopsis species (Aegean Sea, Greece). Toxicon 2008; 51(3): 418-427.

24. de Haro L. Intoxications par organismes aquatiques. Med Trop (Mars) 2008; 68(4): 367374.

\section{Figures}

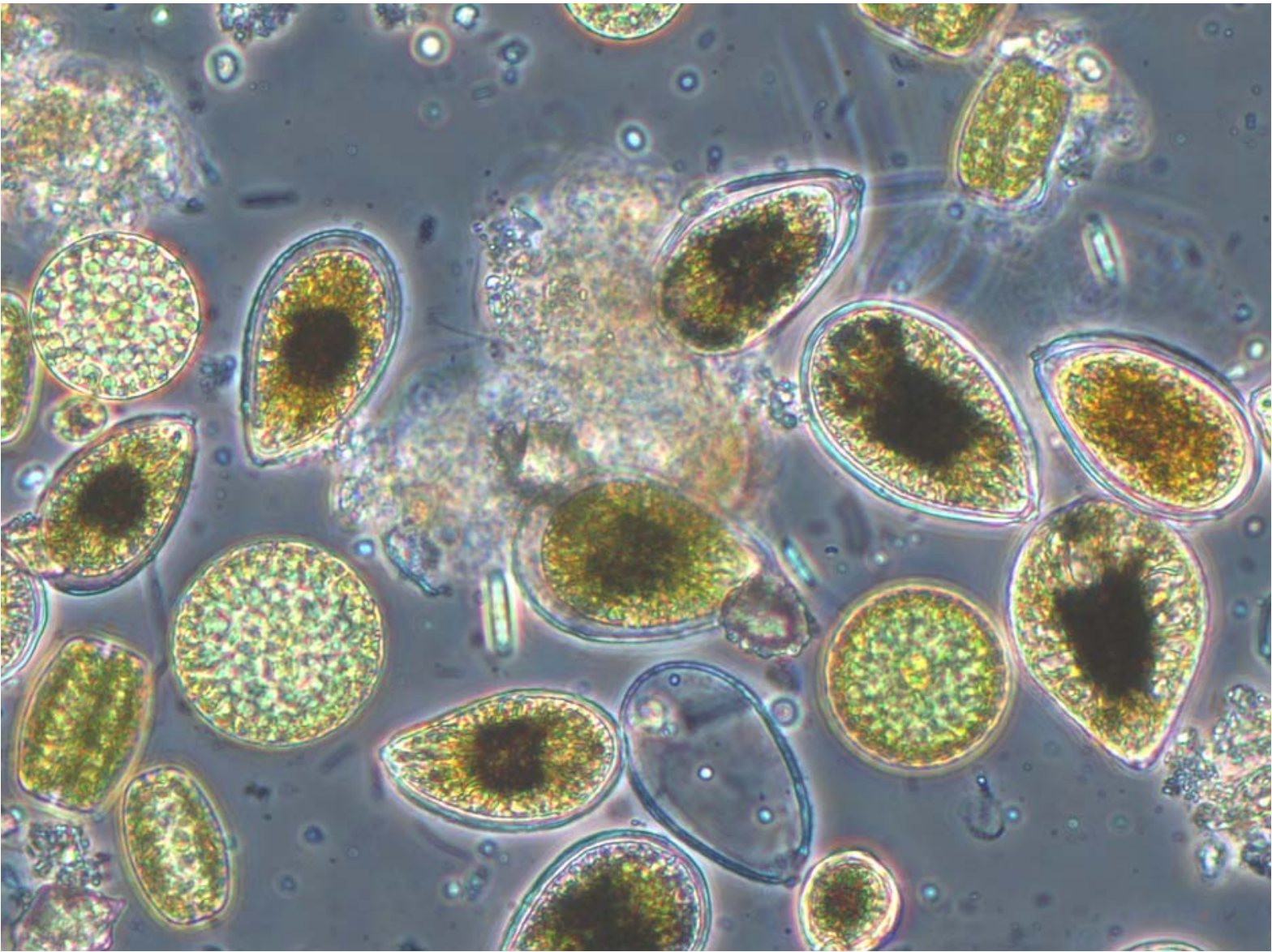

Figure 1: Epibenthic Ostreopsis (approximate cell length: $55 \mu \mathrm{m}$, in association with centric diatoms) during a bloom event in the cove of Pomègues (Frioul Island in Marseille) on August, 4, 2009 (photography by Hubert Grossel, IFREMER) (colored picture online only). 


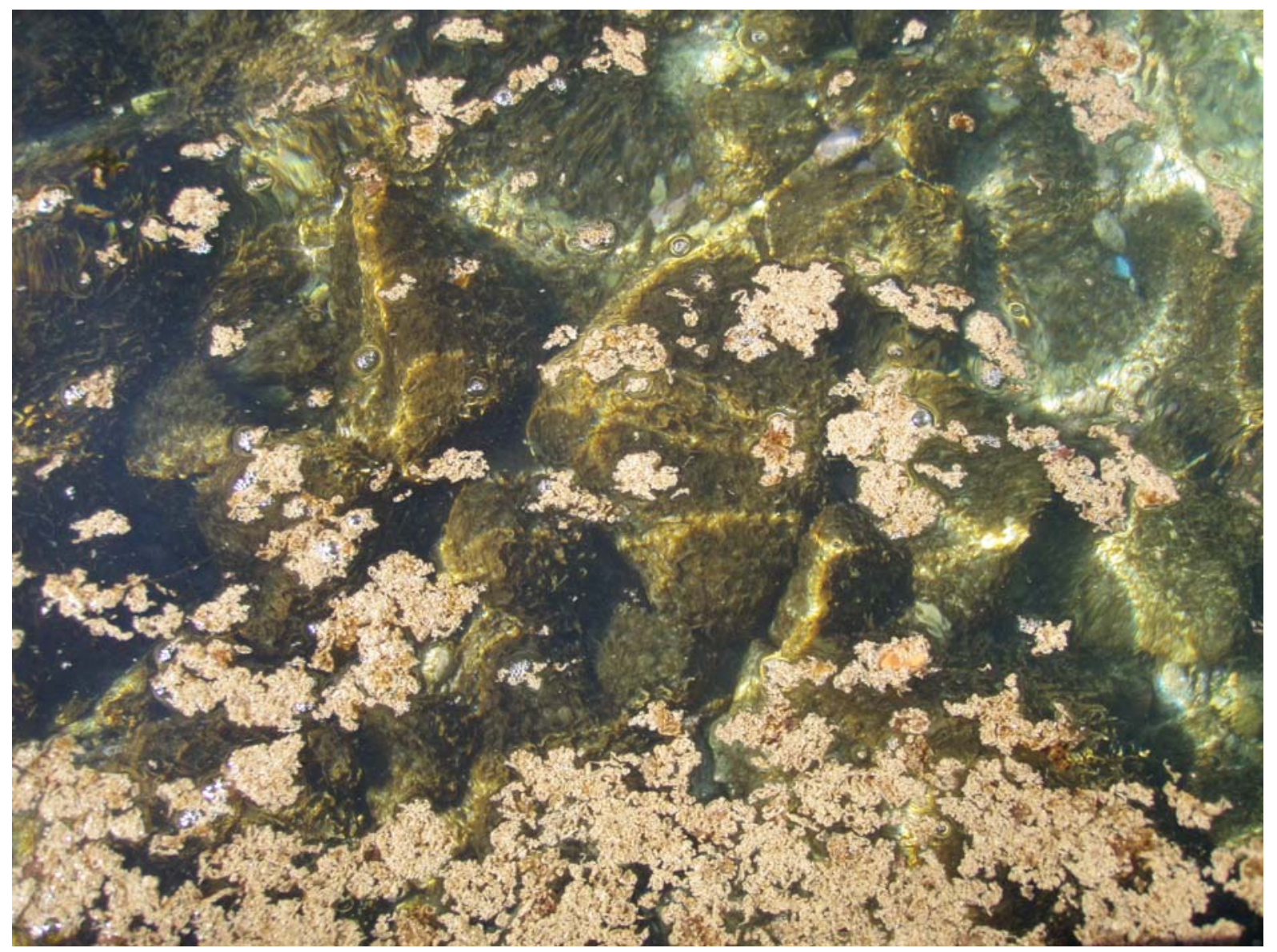

Figure 2: Ostreopsis clusters during bloom event observed in the cove of Pomègues on August 4, 2009 (photography by P.Vidal, CEEP Frioul Island). The cells in figure 1 come from the algal cover on the rocks underlying the surface carrying the bloom (colored picture online only).

\section{Tables}


Table 1: Details of 9 Ostreopsis blooms in the French Mediterranean Coast and Monaco with clinical feature of patients.

NSAID = Non-Steroid Anti-Inflammatory Drug.

Legend: French department codes: $06=$ Alpes Maritimes, $13=$ Bouches du Rhône, $83=$ Var.

Weeks are presented by numbers (example: in $2006, W 30=$ week $n^{\circ} 30$, between the $24^{\text {th }}$ and the $30^{\text {th }}$ of July).

Preventative measures: "Closed beach" refers to access being prevented by the Coast Guard, "Swimming not recommended" indicates that access to the sand is allowed but swimming is only permitted in certain areas.

\begin{tabular}{|c|c|c|c|c|c|c|c|c|c|c|}
\hline Years & 2006 & 2007 & \multicolumn{5}{|c|}{2008} & \multicolumn{2}{|c|}{2009} & Total \\
\hline $\begin{array}{l}\text { Weeks of the blooms } \\
\text { (more than } 30000 \\
\text { cells I Litre of } \\
\text { seawater) }\end{array}$ & W30 & W33 & W25 & W27-29 & W30 & W32-33 & W34-36 & W30-31 & W36 & $\begin{array}{c}1 \text { in June } \\
1 \text { in July } \\
6 \text { in August } \\
1 \text { in } \\
\text { September }\end{array}$ \\
\hline $\begin{array}{l}\text { Beach, City } \\
\text { (department code) }\end{array}$ & $\begin{array}{c}\text { Morgiret } \\
\text { creek, } \\
\text { Frioul Island, } \\
\text { Marseille (13) }\end{array}$ & $\begin{array}{l}\text { Méjan beach, } \\
\text { Toulon (83) }\end{array}$ & $\begin{array}{l}\text { Aygulf beach, } \\
\text { Fréjus (83) }\end{array}$ & $\begin{array}{l}\text { Larvotto } \\
\text { beach, } \\
\text { Monaco }\end{array}$ & $\begin{array}{l}\text { Marinière } \\
\text { beach, } \\
\text { Villefranche } \\
(06)\end{array}$ & $\begin{array}{l}\text { Réserve } \\
\text { beach, } \\
\text { Nice }(06)\end{array}$ & $\begin{array}{c}\text { Morgiret } \\
\text { creek, } \\
\text { Frioul Island, } \\
\text { Marseille (13) }\end{array}$ & $\begin{array}{l}\text { Marinière } \\
\text { beach, } \\
\text { Villefranche } \\
(06) \\
\end{array}$ & $\begin{array}{c}\text { Morgiret } \\
\text { creek, } \\
\text { Frioul Island, } \\
\text { Marseille (13) }\end{array}$ & $\begin{array}{c}\text { 3 French } \\
\text { departments } \\
\text { and Monaco }\end{array}$ \\
\hline $\begin{array}{l}\text { Number of patients } \\
\text { (children/adults) }\end{array}$ & $\begin{array}{c}4 \\
(0 / 4)\end{array}$ & 0 & 0 & $\begin{array}{c}7 \\
(3 / 4)\end{array}$ & 0 & $\begin{array}{c}4 \\
(1 / 3)\end{array}$ & $\begin{array}{c}21 \\
(2 / 19)\end{array}$ & $\begin{array}{c}11 \\
(10 / 1) \\
\end{array}$ & 0 & $\begin{array}{c}47 \\
(16 / 31)\end{array}$ \\
\hline Circumstances & 4 divers & I & I & $\begin{array}{l}1 \text { diver } \\
4 \text { swimmers } \\
2 \text { waterside } \\
\text { residents }\end{array}$ & I & 4 swimmers & $\begin{array}{c}1 \text { diver } \\
20 \text { swimmers }\end{array}$ & $\begin{array}{c}1 \text { diver } \\
10 \text { swimmers }\end{array}$ & I & $\begin{array}{l}7 \text { divers } \\
38 \text { swimmers } \\
2 \text { waterside } \\
\text { residents }\end{array}$ \\
\hline $\begin{array}{l}\text { Skin irritation with } \\
\text { pruritus }\end{array}$ & 0 & I & I & 4 & I & 1 & 15 & 11 & I & $31(66 \%)$ \\
\hline $\begin{array}{l}\text { Mucosal irritation } \\
\text { (eyes, nose, mouth) }\end{array}$ & 4 & I & I & 3 & I & 2 & 6 & 1 & I & $16(34 \%)$ \\
\hline $\begin{array}{l}\text { General symptoms } \\
\text {. fever } \\
\text {. headache } \\
\text {. dizziness } \\
\text {. diarrhoea }\end{array}$ & $\begin{array}{l}1 \\
4 \\
0 \\
1\end{array}$ & I & I & $\begin{array}{l}0 \\
0 \\
0 \\
0\end{array}$ & I & $\begin{array}{l}4 \\
0 \\
0 \\
0\end{array}$ & $\begin{array}{l}0 \\
0 \\
0 \\
0\end{array}$ & $\begin{array}{l}0 \\
1 \\
1 \\
0\end{array}$ & I & $\begin{array}{l}5(11 \%) \\
5(11 \%) \\
1(2 \%) \\
1(2 \%)\end{array}$ \\
\hline $\begin{array}{l}\text { Delay of recovery } \\
\text { with / without NSAID }\end{array}$ & $\begin{array}{c}\text { None } / \\
12 \text { to } 14 \mathrm{H}\end{array}$ & I & I & $\begin{array}{c}8 \mathrm{H} / \\
12 \text { to } 72 \mathrm{H}\end{array}$ & I & $\begin{array}{l}10 \text { to } 12 \mathrm{H} / \\
16 \text { to } 24 \mathrm{H}\end{array}$ & $\begin{array}{l}6 \text { to } 12 \mathrm{H} / \\
12 \text { to } 48 \mathrm{H}\end{array}$ & $\begin{array}{c}4 \text { to } 6 \mathrm{H} / \\
14 \mathrm{H}\end{array}$ & I & $\begin{array}{l}4 \text { to } 12 \mathrm{HI} \\
12 \text { to } 72 \mathrm{H}\end{array}$ \\
\hline $\begin{array}{l}\text { Preventative } \\
\text { measures }\end{array}$ & Closed beach & $\begin{array}{l}\text { Swimming } \\
\text { not } \\
\text { recommende } \\
d\end{array}$ & $\begin{array}{l}\text { Swimming } \\
\text { not } \\
\text { recommende } \\
\text { d }\end{array}$ & $\begin{array}{l}\text { Swimming } \\
\text { not } \\
\text { recommende } \\
d\end{array}$ & Closed beach & $\begin{array}{l}\text { Swimming } \\
\text { not } \\
\text { recommende } \\
\text { d }\end{array}$ & Closed beach & $\begin{array}{l}\text { Closed } \\
\text { beach }\end{array}$ & $\begin{array}{l}\text { Closed } \\
\text { beach }\end{array}$ & $\begin{array}{l}5 \text { Closed } \\
\text { beaches }\end{array}$ \\
\hline
\end{tabular}

